\title{
Students' Dicipline in Mathematics Learning During Covid-19 Pandemic
}

\author{
Fina Hanifa Hidayati ${ }^{1 *}$, Firsta Adilaturrahmah ${ }^{2}$ \\ ${ }^{1,2}$ Universitas Islam Negeri Sunan Kalijaga Yogyakarta \\ *fina.hidayati@uin-suka.ac.id
}

Received: June 2021. Accepted: July 2021. Published: July 2021.

\begin{abstract}
The low level of student discipline in learning mathematics can affect student learning outcomes. Students' discipline in learning during a pandemic that takes place online is difficult to pay attention to. Therefore, it is necessary to conduct research to determine and observe the level of students' discipline. This article aims to describe the level of discipline of junior high school students in participating in mathematics lessons during the Covid-19 pandemic. This is a qualitative descriptive case study research. The subjects in this study were 25 grade VII students of MTs Al-Amin Cikaso for the academic year 2020/2021. Data collection was done by interview, observation, and documentation. Technical data analysis includes data reduction, data presentation, and drawing conclusions. The results showed that: (1) the students had a high level of discipline in obeying school rules, (2) the students had a low level of discipline in participating in ongoing learning, (3) the students had a high level of discipline in carrying out the duties of the teacher, and (4) the students have a moderate level of discipline in carrying out learning at home.

Keywords: learning discipline, learning mathematics, covid-19 pandemic.
\end{abstract}

How to Cite: Hidayati, F. H. \& Adilaturrahmah, F. (2021). Students' Dicipline in Mathematics Learning During Covid-19 Pandemic. Journal of Medives: Journal of Mathematics Education IKIP Veteran Semarang, 5(2), 391-401. 


\section{PENDAHULUAN}

Matematika merupakan ilmu yang penting dan banyak digunakan dalam kehidupan manusia. Matematika juga sebagai ilmu dasar yang sangat berhubungan dengan ilmu pengetahuan lainnya. Menurut Susanto (dalam Romdhoni, 2020) matematika merupakan salah satu disiplin ilmu yang dapat meningkatkan kemampuan berpikir dan berargumentasi, memberikan kontribusi dalam penyelesaian masalah sehari-hari dan dalam dunia kerja serta memberikan dukungan dalam pengembangan ilmu pengetahuan dan teknologi.

Pentingnya matematika bagi kehidupan belum dapat disadari oleh setiap manusia, khususnya siswa. (Wirantasa, 2017) mengatakan bahwa banyak siswa yang masih memandang matematika sebelah mata. Mereka tidak memahami tentang pentingnya matematika dalam kehidupan sehari-hari, padahal banyak sekali aktivitas masyarakat yang menggunakan konsep matematika. Berawal dari pandangan ini, para siswa menjadikan matematika sebagai mata pelajaran yang sulit dipelajari, bahkan menjadi momok yang menakutkan bagi siswa.

Pandangan siswa terhadap matematika juga dapat menurunkan minat dan motivasi siswa dalam belajar matematika. Rendahnya minat dan motivasi siswa mampu mempengaruhi sikap siswa dalam proses belajar matematika, salah satunya sikap disiplin dalam belajar. Tingkat kedisiplinan siswa menjadi salah satu faktor keberhasilan siswa dalam belajar matematika. Menurut (Di \& Negeri, 2020) sikap disiplin mampu mem- pengaruhi pemahaman siswa dalam belajar, yakni kurangnya kedisiplinan siswa saat mengikuti pembelajaran matematika dapat menjadi penyebab kurangnya pemahaman siswa.

Disiplin merupakan sikap patuh dalam menaati aturan atau tata tertib yang berlaku. Ariananda (2014) mendefinisikan disiplin secara lengkap yang berarti suatu kesadaran dalam melakukan suatu hal dengan penuh tanggung jawab untuk tertib dan teratur mengikuti peraturan yang berlaku serta atas kehendak sendiri tanpa paksaan dari siapapun. Sedangkan disiplin belajar berarti sikap patuh dan taat terhadap tata tertib dan peraturan dalam belajar baik di sekolah atau di rumah. Menurut (Yuliantika, 2017) kedisiplinan belajar merupakan suatu kondisi belajar yang dilakukan oleh siswa untuk mencari pengetahuan baru dengan menunjukkan nilai-nilai ketaatan, kepatuhan, dan ketertiban, yang sesuai dengan harapan untuk mencapai tujuan pembelajaran.

Tingkat kedisiplinan siswa Indonesia dalam belajar matematika masih tergolong rendah. (Khristiyanta, 2015) mengatakan bahwa tingkat kedisiplinan siswa dalam belajar masih sangat rendah. Hal tersebut ditunjukkan oleh sikap siswa yang masih kurang mematuhi peraturan di sekolah, seperti sering membolos, terlambat masuk kelas, tidak mengerjakan tugas sekolah, dan tidak berpakaian rapi. Selain itu, kedisiplinan siswa juga dipengaruhi oleh faktor eksternal berupa metode pembelajaran yang digunakan oleh guru. Menurut (Pujiastuti, 2015) strategi pelaksanaan pembelajaran tradisional yang masih banyak digunakan oleh guru 
di Indonesia belum mampu menumbuhkan kebiasaan disiplin bagi siswa. Dengan demikian, pemilihan dan penggunaan metode belajar dapat mempengaruhi tingkat kedisiplinan siswa dalam belajar matematika.

Pembelajaran matematika yang berlangsung saat ini dilaksanakan secara online akibat adanya pandemi covid-19. Melalui surat Edaran Nomor 4 Tahun 2020 tentang pelaksanaan pendidikan dalam masa darurat penyebaran covid19, pemerintah memberikan kebijakan bahwa proses belajar dilaksanakan di rumah melalui Pembelajaran Jarak Jauh (PJJ) untuk memberikan pengalaman belajar yang bermakna bagi siswa. Menurut Undang-Undang No. 20 Tahun 2003 pasal 1 ayat 15 PJJ merupakan pendidikan yang berlangsung secara terpisah antara peserta didik dengan pendidik dengan menggunakan berbagai sumber belajar melalui teknologi komunikasi, informasi, dan media lain. Menurut (Wahyuningsih, 2021) sistem pembelajaran jarak jauh dilaksanakan melalui dua pendekatan, yaitu pembelajaran secara daring (PJJ dalam jaringan) dan pembelajaran secara luring (PJJ luar jaringan).

Pelaksanaan pembelajaran jarak jauh tentu bukan hal yang mudah, apalagi bagi lembaga pendidikan dan siswa yang baru pertama kali merasakannya. Muncul berbagai masalah yang dihadapi oleh siswa dan guru dalam pembelajaran online, termasuk salah satunya mengenai kedisiplinan belajar siswa. (Halimah, S.Ag, 2020) menjelaskan proses pembelajaran yang dilaksanakan secara daring belum efektif karena masih ada siswa yang tidak disiplin dalam proses pembelajaran jarak jauh.

Dari uraian tersebut dapat dipahami bahwa kedisiplinan sangat penting dan bermanfaat untuk mendidik siswa lebih menaati peraturan dan menciptakan pembelajaran yang efektif. Dengan adanya sikap disiplin siswa dalam belajar diharapkan dapat menumbuhkan sikap berusaha dan bekerja keras dalam belajar sehingga hasil belajar matematika siswa dapat lebih meningkat. Dalam hal ini penulis tertarik untuk melakukan analisis tingkat kedisiplinan belajar siswa dalam pembelajaran matematika. Tujuan dari penelitian ini adalah mengetahui tingkat kedisiplinan siswa Sekolah Menengah Pertama dalam melaksanakan pembelajaran matematika yang berlangsung pada masa pandemi covid-19 baik secara daring maupun luring.

\section{METODE PENELITIAN}

Penelitian ini merupakan penelitian studi kasus deskriptif kualitatif yang bertujuan untuk mendeskripsikan kedisiplinan siswa dalam pembelajaran matematika pada masa pandemi covid19. Penelitian ini dilaksanakan pada salah satu Sekolah Menengah Pertama di Kabupaten Ciamis, yaitu MTs Al-Amin Cikaso. Subjek penelitian adalah siswa kelas VII MTs Al-Amin Cikaso Tahun Ajaran 2020/2021 sebanyak 25 siswa. Pengumpulan data dilakukan dengan observasi, dokumentasi dan wawancara secara langsung kepada beberapa siswa serta dilakukan melalui pengisian angket oleh seluruh subjek penelitian. Instrumen yang dikembangkan dalam penelitian ini berupa instrumen angket 
yang berisi beberapa pertanyaan mengenai kedisiplinan dengan mengacu pada beberapa Indikator kedisiplinan menurut (Daryanto, 2013), yaitu (1) ketaatan terhadap tata tertib sekolah, (2) ketaatan terhadap kegiatan pembelajaran di sekolah, (3) ketaatan dalam melaksanakan tugas pelajaran, dan (4) kedisiplinan belajar di rumah, dengan masing-masing aspek pada setiap indikatornya.

Analisis data penelitian dilakukan menggunakan model analisis Miles \& Huberman (Sugiyono, 2017) yang terdiri dari tiga tahap, yaitu reduksi data, penyajian data, serta penarikan dan verifikasi kesimpulan. Analisis data penelitian tahap reduksi data merupakan tahap mengumpulkan seluruh informasi yang dibutuhkan dari hasil wawancara lalu di kelompokkan datanya. Tahap display data merupakan pemaparan data yang diperlukan dalam penelitian dan yang tidak perlu dibuang. Tahap penarikan dan verifikasi kesimpulan adalah tahap interpretasi data penelitian untuk ditarik kesimpulan berdasarkan fenomena yang didapatkan.

Data kedisiplinan yang diperoleh melalui angket dihitung rata-rata setiap indikatornya kemudikan dikategorikan tingkat kedisiplinannya seperti pada Tabel 1 (Muladi, 2015).

Tabel 1. Kategori Kedisiplinan

\begin{tabular}{cc}
\hline Rata-Rata & Kategori \\
\hline $80 \% \leq \bar{X} \leq 100 \%$ & Sangat Tinggi \\
$66 \% \leq \bar{X} \leq 79 \%$ & Tinggi \\
$56 \% \leq \bar{X} \leq 65 \%$ & Sedang \\
$41 \% \leq \bar{X} \leq 55 \%$ & Rendah \\
$0 \% \leq \bar{X} \leq 40 \%$ & Sangat Rendah \\
\hline
\end{tabular}

\section{HASIL DAN PEMBAHASAN}

Pembelajaran di sekolah pada masa pandemi covid-19 dilaksanakan dengan sistem Pembelajaran Jarak Jauh (PJJ), dengan dua metode yaitu pembelajaran daring dan pembelajaran luring. Pembelajaran daring dilaksanakan secara online melalui media yang dapat menghubungkan para siswa dan guru secara tidak langsung atau melalui online. (Kuntarto, 2017) menjelaskan perbedaan pembelajaran daring dengan pembelajaran konvensional, yakni pembelajaran daring dilaksanakan berbasis internet menggunakan media elektronik sebagai aplikasi pembelajaran untuk menghubungkan pembelajaran. Media yang paling banyak digunakan adalah WhatsApp yang dinilai paling efektif digunakan oleh siswa dan guru dalam pembelajaran online. Kefektifan tersebut sesuai dengan (Anugrahana, 2020) yang menyebutkan alasan guru lebih banyak menggunakan WhatsApp karena lebih praktis, hemat kuota, lebih mudah dipahami dan dijangkau oleh semua kalangan.

Pembelajaran luring dilaksanakan secara tatap muka tanpa menggunakan media berbasis jaringan internet. Menurut (Ermayulis, 2021) dalam pembelajaran luring sama sekali tidak terhubung dengan jaringan internet, salah satu contohnya adalah aktivitas offline conference yang dilaksanakan secara langsung tanpa menggunakan internet. Kedisiplinan siswa pada pembelajaran luring juga perlu diperhatikan karena belum tentu setiap siswa memiliki sikap disiplin yang tinggi. (Legiman \& Artikel, 2021) menjelaskan bahwa tingkat disiplin 
siswa dalam pembelajaran tatap muka pada masa pandemi covid-19 masih rendah dan rendahnya disiplin siswa tersebut berdampak pada hasil belajar siswa.

Kedisiplinan siswa dalam belajar matematika pada masa pandemi memang sulit diperhatikan, karena metode pembelajaran secara online yang tidak memungkinkan guru untuk mengamati kegiatan siswa secara langsung. Namun, bukan berati kedisiplinan siswa sama sekali tidak dapat diamati oleh guru.

Dalam penelitian ini, kedisiplinan siswa diukur melalui beberapa indikator kedisiplinan belajar siswa menurut Daryanto (2013), yakni: (1) ketaatan terhadap tata tertib sekolah, (2) ketaatan terhadap kegiatan pembelajaran di sekolah, (3) ketaatan dalam melaksanakan tugas pelajaran, dan (4) kedisiplinan belajar di rumah. Hasil persentase kedisiplinan siswa dapat dilihat dalam Tabel 2.

Tabel 2. Persentase Kedisiplinan Belajar Siswa

\begin{tabular}{|c|c|c|c|c|}
\hline \multirow{2}{*}{ Indikator } & \multicolumn{3}{|c|}{ Aspek Indikator } & \multirow[t]{2}{*}{ Rata-rata } \\
\hline & 1 & 2 & 3 & \\
\hline $\begin{array}{l}\text { Mematuhi } \\
\text { Peraturan } \\
\text { Sekolah }\end{array}$ & $72 \%$ & $76 \%$ & $68 \%$ & $72 \%$ \\
\hline $\begin{array}{l}\text { Mematuhi } \\
\text { Kegiatan } \\
\text { Pembelajaran }\end{array}$ & $68 \%$ & $48 \%$ & $44 \%$ & $53.33 \%$ \\
\hline $\begin{array}{l}\text { Disiplin } \\
\text { Melaksanakan } \\
\text { Tugas }\end{array}$ & $72 \%$ & $40 \%$ & $96 \%$ & $69.33 \%$ \\
\hline $\begin{array}{l}\text { Disiplin } \\
\text { Belajar di } \\
\text { rumah }\end{array}$ & $20 \%$ & $64 \%$ & $92 \%$ & $58,67 \%$ \\
\hline
\end{tabular}

Tabel 2 menunjukkan tingkat kedisiplinan siswa berdasarkan beberapa indikator disiplin belajar siswa. Pada setiap indikator diukur beberapa aspek untuk mengetahui lebih lanjut mengenai tingkat kedisiplinan siswa dalam belajar matematika. Berdasarkan hasil penelitian, maka dapat diuraikan pembahasan mengenai analisis beberapa aspek pada setiap indikator kedisiplinan siswa sebagai berikut:

\section{Ketaatan terhadap Tata Tertib Sekolah}

Aspek indikator ketaatan siswa terhadap peraturan sekolah yang diukur dalam penelitian ini meliputi aspek: (1) ketertiban dalam memulai pembelajaran, (2) ketertiban ketika pembelajaran berlangsung, dan (3) ketaatan dalam kehadiran belajar. Berdasarkan tinjauan dari aspek indikator kedisiplinan siswa terhadap tata tertib sekolah dalam menaati peraturan masuk kelas, sebanyak $72 \%$ siswa tidak pernah terlambat masuk kelas, yang berarti bahwa sebagian besar siswa selalu mengikuti pembelajaran dengan tepat waktu. Pada pembelajaran daring, kedisiplinan siswa saat masuk kelas dilihat dari kedisiplinan dalam memulai kegiatan pembelajaran yang dilaksanakan melalui media berbasis internet.

Berdasarkan tinjauan dari aspek indikator kedisiplinan siswa terhadap tata tertib sekolah dalam menaati peraturan ketika pembelajaran berlangsung, diperoleh data sebesar $76 \%$ siswa tidak pernah meninggalkan kelas tanpa seizin guru. Data tersebut menunjukkan tingkat kedisiplinan siswa 
belajar matematika selama proses pembelajaran berlangsung. Dengan demikian dapat terlihat bahwa sebagian besar siswa MTs Al-Amin Cikasso disiplin dalam mengikuti pembelajaran yang sedang berlangsung.

Berdasarkan tinjauan dari aspek indikator kedisiplinan siswa terhadap tata tertib sekolah dalam hal membolos, diperoleh data sebesar $68 \%$ siswa tidak pernah membolos. Hal ini menunjukkan bahwa sebagian besar siswa cukup disiplin kaitannya dengan kehadiran belajar di sekolah atau ketika pembelajaran berlangsung.

Berdasarkan analisis tersebut dan dilengkapi dengan hasil wawancara terhadap beberapa siswa, diperoleh kesimpulan bahwa siswa-siswi MTs AlAmin Cikaso memiliki tingkat kedisiplinan yang tinggi dalam menaati peraturan yang berlaku di sekolah dengan rata-rata sebesar $72 \%$. Seorang siswa menjelaskan bahwa pihak sekolah memberlakukan aturan secara ketat dan bagi siapa pun yang melanggar akan memperoleh konsekuensinya. Hal tersebut dilakukan dengan tujuan untuk melatih siswa mematuhi tata tertib yang berlaku dan menumbuhkan sikap kedisiplinan siswa dalam belajar. Dalam hal ini peran sekolah yang dilaksanakan oleh kepala sekolah dan jajarannya mampu meningkatkan kedisiplinan siswa. Hal ini sesuai dengan hasil penelitian yang dilaksanakan (Fawaid, 2017), (Kurniasih \& Wijaya, 2019), dan (Sutrisno, 2020) bahwa tata tertib sekolah yang diterapkan dengan baik melalui keterlibatan kepala sekolah dapat meningkatkan pendidikan karakter kedisiplinan siswa.

\section{Ketaatan terhadap Kegiatan Pembelajaran}

Aspek indikator ketaatan siswa terhadap kegiatan pembelajaran yang diukur meliputi beberapa aspek, yaitu: aspek (1) kedisiplinan ketika memperhatikan penjelasan guru, (2) kedisiplinan dalam bertanya kepada guru/teman, dan (3) kedisiplinan dalam hal mencatat materi matematika. Berdasarkan tinjauan dari aspek indikator ketaatan siswa terhadap kegiatan belajar di sekolah dalam memperhatikan penjelasan guru ketika pembelajaran berlangsung diperoleh sebesar 68\% siswa dapat memperhatikan dengan benar dan serius. Selama proses pembelajaran mereka tidak pernah membuat kegaduhan dan mengganggu teman, baik dalam pembelajaran daring maupun luring. Dengan demikian terlihat bahwa siswa MTs Al-Amin Cikaso dapat menaati kegiatan belajar di sekolah dengan baik dalam memperhatikan penjelasan guru.

Berdasarkan tinjauan dari aspek indikator ketaatan siswa belajar di sekolah dalam bertanya kepada guru/teman ketika tidak memahami pelajaran diperoleh sebanyak $48 \%$ siswa sering bertanya kepada guru atau teman untuk menambah pemahaman mereka dalam belajar. Keaktifan mereka dalam belajar selain untuk menambah pengetahuan, juga menjadi salah satu poin penilaian guru terhadap siswa dalam hal sikap dan keterampilan. Dari pemaparan tersebut dapat diperoleh kesimpulan bahwa siswa aktif bertanya kepada guru atau teman ketika belum memahami materi matematika yang sedang dipelajari. 
Berdasarkan tinjauan dari aspek indikator ketaatan siswa belajar di sekolah dalam mencatat materi matematika yang dipelajari diperoleh sebanyak $44 \%$ siswa sering mencatat materi matematika yang diberikan oleh guru. Mereka memiliki catatan yang lengkap mengenai setiap materi matematika yang disampaikan oleh guru. Selain itu, siswa juga memiliki buku pegangan siswa yang digunakan guru sebagai sumber belajar. Dengan demikian terlihat bahwa para siswa memiliki disiplin yang baik dalam mencatat setiap materi yang telah dipelajari.

Berdasarkan hasil dari ketiga aspek tersebut, diperoleh kesimpulan bahwa tingkat kedisiplinan siswa dalam mengikuti pembelajaran masih rendah yaitu dengan rata-rata 53\%. Jika kita lihat dengan persentase tersebut artinya sebagian siswa disiplin dalam mengikuti kegiatan pembelajaran sedangakan Sebagian yang lain tidak. Siswa aktif memperhatikan penjelasan guru dan serius selama kegiatan pembelajaran. Namun para siswa belum memiliki sikap disiplin tinggi dalam bertanya kepada teman/guru serta dalam mencatat materi yang disampaikan oleh guru. Berdasarkan hasil wawancara, beberapa siswa mengatakan mereka terkadang merasa malas untuk mencatat, bahkan ada siswa yang tidak memiliki buku sumber belajar karena tidak memiliki biaya untuk membeli buku tersebut. Hal tersebut perlu mendapat perhatian dari pihak sekolah atau guru dalam memfasilitasi belajar siswa agar seluruh siswa dapat memahami konsep matematika.

\section{Ketaatan dalam Mengerjakan Tugas Pelajaran}

Aspek indikator ketaatan siswa dalam mengerjakan tugas matematika diukur meliputi beberapa aspek, yaitu: aspek (1) kedisiplinan dalam mengerjakan tugas sendiri, (2) kedisiplinan dalam berdiskusi dengan teman, dan (3) kedisiplinan dalam ketepatan waktu pengumpulan tugas. Berdasarkan tinjauan dari aspek indikator kedisiplinan siswa mengerjakan tugas ketika mengerjakan tugas sendiri diperoleh $72 \%$ siswa sering mengerjakan tugas sendiri. Para siswa terbiasa mengerjakan tugas sendiri tanpa meminta bantuan dari teman lain. Hal tersebut menunjukkan tingkat kemandirian siswa yang tinggi dalam mengerjakan tugas matematika.

Berdasarkan tinjauan dari aspek indikator kedisiplinan siswa mengerjakan tugas dalam berdiskusi dengan teman untuk menyelesaikan tugas diperoleh data sebesar $40 \%$ siswa sering berdiskusi dengan teman untuk menyelesaikan tugas. Hal ini menunjukkan bahwa keaktifan siswa untuk berdiskusi dengan teman sebanding dengan keaktifan dalam bertanya kepada guru, yakni siswa-siswi belum memiliki sikap aktif berdiskusi yang tinggi. Dengan demikian dapat diambil kesimpulan bahwa sebagian besar siswa jarang melakukan diskusi dengan teman sebaya dalam menyelesaikan tugas dari sekolah.

Berdasarkan tinjauan dari aspek indikator kedisiplinan siswa mengerjakan tugas dalam pengumpulan tugas, $96 \%$ siswa sering mengumpulkan tugas tepat waktu. Para siswa sudah terlatih untuk disiplin dalam hal waktu, baik dalam mengikuti pembelajaran atau 
dalam hal pengumpulan tugas. Dengan demikian dapat diambil kesimpulan bahwa siswa MTs Al-Amin Cikaso memiliki disiplin yang tinggi dalam ketepatan waktu mengumpulkan tugas.

Berdasarkan hasil analisis tersebut dapat diambil kesimpulan bahwa siswa MTs Al-Amin Cikaso memiliki tingkat kedisiplinan yang tinggi dalam mengerjakan tugas pelajaran yaitu dengan rata-rata sebesar $69.33 \%$. Siswa memiliki tingkat kemandirian yang baik untuk mengerjakan tugas sendiri dan memiliki sikap disiplin yang tinggi dalam ketepatan waktu mengumpulkan tugas. Namun, siswa-siswi MTs AlAmin Cikaso belum memiliki keaktifan yang tinggi dalam berdiskusi dengan teman untuk menyelesaikan tugas.

\section{Kedisiplinan Belajar di Rumah}

Aspek indikator kedisiplinan siswa belajar di rumah atau di luar jam pelajaran yang diukur dalam penelitian ini meliputi aspek: (1) kedisiplinan siswa menambah jam pelajaran di luar pembelajaran sekolah, (2) melaksanakan belajar tidak hanya jika ada ujian, dan (3) mempersiapkan alat tulis sendiri. Berdasarkan tinjauan dari aspek indikator kedisiplinan siswa belajar di rumah ketika siswa belajar di luar jam pelajaran, diperoleh data sebesar $20 \%$ siswa sering belajar di luar jam pelajaran sekolah. Data tersebut menunjukkan kesadaran siswa dalam kemandirian belajar di luar jam pelajaran sekolah masih sangat rendah. Hal ini diperkuat dengan hasil wawancara bahwa siswa cukup lelah dengan pembelajaran online yang mengharuskan mereka menatap layar laptop maupun handphone sehingga bagi mereka cukup untuk belajar pada jam pelajaran dan memilih untuk beristirahat di luar jam pelajaran. Selain itu, beberapa siswa juga mengatakan mulai bosan dan lelah mengikuti pelajaran secara daring. Hal ini lambat laun akan membuat pembelajaran daring menjadi pembelajaran yang enggan dilakukan siswa (Ambarsari, 2021).

Berdasarkan tinjauan dari aspek indikator kedisiplinan belajar di rumah ketika belajar hanya jika akan ada ujian, diperoleh data $64 \%$ siswa tidak pernah belajar hanya jika akan ujian. Hal tersebut menunjukkan kesadaran siswa yang cukup baik untuk menyiapkan diri sebelum melaksanakan ujian akhir sekolah. Dengan demikian dapat diambil kesimpulan bahwa siswa MTs Al-Amin Cikaso memiliki disiplin yang cukup baik dalam kedisiplinan belajar dirumah.

Berdasarkan tinjauan dari aspek indikator kedisiplinan siswa dalam mempersiapkan alat tulis sendiri untuk belajar, diperoleh data sebanyak 92\% siswa sering menyiapkan alat tulis sendiri. Siswa-siswi MTs AL-Amin telah memiliki kesadaran yang tinggi untuk belajar mandiri dengan mempersiapkan segala sesuatu yang dibutuhkan dalam belajar. Dengan demikian dapat diambil kesimpulan bahwa para siswa memiliki disiplin yang tinggi dalam kedisiplinan diri untuk menyiapkan peralatan belajar sendiri.

Berdasarkan hasil analisis di atas, diperoleh kesimpulan bahwa para siswa memiliki kedisiplinan yang sedang (dengan persentase 58,67\%) dalam melaksanakan belajar di rumah. Mereka memiliki kesadaran kurang untuk menambah jam belajar di luar jam mata 
pelajaran yang berlaku dari sekolah. Namun mereka mengaku selalu belajar rutin, tidak hanya saat akan menghadapi ujian. Para siswa juga memiliki tingkat kedisiplinan dan kemandirian yang tinggi untuk mempersiapkan segala sesuatu yang dibutuhkan untuk membantu belajar siswa. Kedisiplinan siswa dalam belajar di rumah juga tak lepas dari peran serta keluarga, hal ini dipertegas dalam wawancara bahwa keluarga berperan aktif dalam membatu siswa untuk belajar di rumah sehingga beberapa siswa senantiasa belajar meski di luar jam pelajaran, meski tidak pada saat ujian serta menyiapkan segala perlengkapan belajar diantaranya adalah alat tulis. Hal ini sesuai dengan penelitian yang dilaksanakan (Yanti \& Marimin, 2017) bahwa peran keluarga mempengaruhi kedisiplinan siswa.

\section{PENUTUP}

Hasil penelitian menunjukkan tingkat kedisiplinan belajar matematika siswa-siswi MTs Al-Amin Cikaso berdasarkan beberapa indikator kedisiplinan belajar yang digunakan. Berdasarkan hasil analisis data yang terkumpul dapat disimpulkan bahwa: (1) para siswa memiliki tingkat kedisiplinan yang tinggi dalam menaati tata tertib sekolah; (2) para siswa memiliki tingkat kedisiplinan yang rendah dalam mengikuti pembelajaran yang sedang berlangsung; (3) para siswa memiliki tingkat kedisiplinan yang tinggi dalam melaksanakan tugas dari guru; dan (4) para siswa memiliki kedisiplinan yang sedang dalam melaksanakan pembelajaran di rumah. Sikap kedisiplinan siswa mampu mempengaruhi hasil belajar siswa
(Ariananda et al., 2016) (Saidatul et al., 2019)(Solihin, 2017)(Wirantasa, 2017), sehingga bagi para tenaga pendidik disarankan untuk memperhatikan dan meningkatkan kedisiplinan siswa dalam belajar supaya siswa memiliki hasil belajar matematika yang tinggi dan mampu mencapai tujuan pembelajaran yang diharapkan. Untuk meningkatkan kedisiplinan, strategi yang dapat dilakukan adalah dengan menyesuaikan visi misi, motto dan tujuan sekolah, melaksanakan kegiatan sosialisai, pembimbingan, dan pengawasan kedisiplinan, melaksanakan tata tertib disiplin, serta sosialisasi materi disiplin dan aplikasinya (Manshur, 2019).

\section{DAFTAR PUSTAKA}

Ambarsari, R. Y. (2021). Evaluasi Pembelajaran Daring Selama Pandemi Covid-19 Di Kecamatan Bulukerto Wonogiri. Jurnal Mitra Swara Ganesha, 8(1).

Anugrahana, A. (2020). Hambatan, Solusi dan Harapan: Pembelajaran Daring Selama Masa Pandemi Covid-19 Oleh Guru Sekolah Dasar. Scholaria: Jurnal Pendidikan Dan Kebudayaan, 10(3).

Ariananda, E. S., Hasan, S., \& Rakhman, M. (2016). Pengaruh Kedisiplinan Siswa Di Sekolah Terhadap Prestasi Belajar Siswa Teknik Pendingin. Journal of Mechanical Engineering Education, 1(2).

Daryanto. (2013). Strategi dan Tahap Mengajar. CV Yrama Widya.

Di, S., \& Negeri, S. M. P. (2020). Pengaruh kedisiplinan terhadap pemahaman matematik siswa di smp negeri 1 arjosari. Pendidikan Matematika, 1(1). 
Ermayulis, S. (2021). Penerapan Sistem Pembelajaran DARING di Tengah Pandemi COVID-19. STIT AlKifayah Riau.

Fawaid, M. M. (2017). IMPLEMENTASI TATA TERTIB SEKOLAH DALAM MENINGKATKAN KARAKTER KEDISIPLINAN SISWA. Jurnal Civic Hukum, 2(1).

Halimah, S.Ag, M. p. (2020). Karakter Disiplin Siswa Selama Pembelajaran Daring Masa Pandemic Covid-19 di MTSN 1 Kendari Program studi administrasi pendidikan , universitas muhammadiyah kendari Email : fajrianty07@gmail.com.

Khristiyanta, E. P. (2015). Peningkatan Sikap Kedisiplinan Siswa Sekolah Dasar Melalui Pemanfaatan Media Audio Pendidikan Karakter. Jurnal Kwangsan, 3(1).

Kuntarto, E. (2017). Keefektifan Model Pembelajaran Daring dalam Perkuliahan Bahasa Indonesia di Perguruan Tinggi. Journal Indonesian Language Education and Literature, 3(1).

Kurniasih, F., \& Wijaya, H. (2019). Peran Kepemimpinan Kepala Sekolah Dalam Meningkatkan Kedisiplinan Siswa di SDN Embung Tangar Kecamatan Praya Barat. JUPE: Jurnal Pendidikan Mandala, 4(5).

Legiman, A., \& Artikel, S. (2021). Peningkatan Disiplin Dan Hasil Belajar Matematika Pada Pembelajaran Tatap Muka Masa Pandemi Covid 19 Dengan Tugas Terstruktur. 4(1), 28-33.

Manshur, A. (2019). Strategi Pengembangan Kedisiplinan
Siswa. Al Ulya: Jurnal Pendidikan Islam, 4(1).

Muladi, S. (2015). Upaya Meningkatkan Motivasi Dan Hasil Belajar Dalam Pembelajaran Menggunakan Model Pembelajaran Solving Pundung Bantul. 3, 1-11.

Pujiastuti, T. (2015). Pengaruh Kedisiplinan Siswa Dan Motivasi Belajar Terhadap Prestasi Belajar Matematika Di Mi Kota Salatiga Tahun Pelajaran 2014/2015.

Saidatul, A., Babo, R., \& Muhajir, M. (2019). Hubungan antara Kedisiplinan Siswa dengan Hasil Belajar Pendidikan Pancasila dan Kewarganegaraan Siswa Kelas XII di SMA Somba Opu Sungguminasa Kabupaten Gowa. JED (Jurnal Etika Demokrasi), 4(2).

Solihin. (2017). Pengaruh Kedisiplinan Terhadap Prestasi Siswa Sman 1 Benai Kabupaten Kuantang Singinggi (Study Kasus Kelas Ix). Jom Fisip, 4(1).

Sugiyono. (2017). Metode Penelitian Kuantitatif, Kualitatif, dan $R \& D$. CV Alfabeta.

Sutrisno, T. (2020). Penerapan Layanan Orientasi pada Materi Pengenalan Tata Tertib Sekolah Dalam Upaya Meningkatkan Kedisiplinan Siswa. MUBTADI: Jurnal Pendidikan Ibtidaiyah, 1(1).

Wahyuningsih, K. S. (2021). Problematika Pembelajaran Daring Di Masa Pandemi Covid19 di SMA Dharma Praja Denpasar. Jurnal Pangkaja, 24(1).

Wirantasa, U. (2017). Pengaruh Kedisiplinan Siswa Terhadap Prestasi Belajar Matematika. Formatif: Jurnal Ilmiah Pendidikan MIPA, 7(1). 
Yanti, Y., \& Marimin. (2017). Pengaruh Motivasi, Lingkungan Keluarga, Dan Teman Sebaya Terhadap Kedisiplinan Siswa. Economic Education Analysis Journal, 6(2), 329-338.

Yuliantika, S. (2017). Analisis faktorFaktor yang Mempengaruhi Disiplin Belajar Siswa Kelas X, XI, dan XII di SMA Bhakti Yasa Singaraja Tahun Pelajaran 2016/2017. Jurnal Pendidikan Ekonomi Undiksha, 9(1). 